\title{
Nanoscale Topographies for Corneal Endothelial Regeneration
}

\author{
Nello Formisano ${ }^{1}$, Gozde Sahin ${ }^{1}$, Pere Català ${ }^{2,3}{ }^{\circledR}$, Roman Truckenmüller ${ }^{1}$, Rudy M. M. A. Nuijts ${ }^{2}$, \\ Mor M. Dickman ${ }^{2}$, Vanessa L. S. LaPointe ${ }^{3}{ }^{(1)}$ and Stefan Giselbrecht ${ }^{1, *}$
}

1 Department of Instructive Biomaterials Engineering, MERLN Institute for Technology-Inspired Regenerative Medicine, Maastricht University, 6229 ER Maastricht, The Netherlands;

n.formisano@maastrichtuniversity.nl (N.F.); g.sahin@maastrichtuniversity.nl (G.S.); r.truckenmuller@maastrichtuniversity.nl (R.T.)

2 University Eye Clinic Maastricht, Maastricht University Medical Center+, 6229 HX Maastricht, The Netherlands; p.catala@maastrichtuniversity.nl (P.C.); rudy.nuijts@mumc.nl (R.M.M.A.N.); mor.dickman@mumc.nl (M.M.D.)

3 Department of Cell Biology-Inspired Tissue Engineering, MERLN Institute for Technology-Inspired Regenerative Medicine, Maastricht University, 6229 ER Maastricht, The Netherlands; v.lapointe@maastrichtuniversity.nl

* Correspondence: s.giselbrecht@maastrichtuniversity.nl

Citation: Formisano, N.; Sahin, G.; Català, P.; Truckenmüller, R.; Nuijts, R.M.M.A.; Dickman, M.M.; LaPointe, V.L.S.; Giselbrecht, S. Nanoscale Topographies for Corneal Endothelial Regeneration. Appl. Sci. 2021, 11, 827 https://doi.org/10.3390/app11020827

Received: 27 December 2020

Accepted: 13 January 2021

Published: 17 January 2021

Publisher's Note: MDPI stays neutral with regard to jurisdictional clai$\mathrm{ms}$ in published maps and institutional affiliations.

Copyright: $\odot 2021$ by the authors. Licensee MDPI, Basel, Switzerland. This article is an open access article distributed under the terms and conditions of the Creative Commons Attribution (CC BY) license (https:// creativecommons.org/licenses/by/ $4.0 /)$.

\begin{abstract}
The corneal endothelium is the innermost layer of the cornea that selectively pumps ions and metabolites and regulates the hydration level of the cornea, ensuring its transparency. Trauma or disease affecting human corneal endothelial cells (hCECs) can result in major imbalances of such transport activity with consequent deterioration or loss of vision. Since tissue transplantation from deceased donors is only available to a fraction of patients worldwide, alternative solutions are urgently needed. Cell therapy approaches, in particular by attempting to expand primary culture of hCECs in vitro, aim to tackle this issue. However, existing cell culture protocols result in limited expansion of this cell type. Recent studies in this field have shown that topographical features with specific dimensions and shapes could improve the efficacy of hCEC expansion. Therefore, potential solutions to overcome the limitation of the conventional culture of hCECs may include recreating nanometer scale topographies (nanotopographies) that mimic essential biophysical cues present in their native environment. In this review, we summarize the current knowledge and understanding of the effect of substrate topographies on the response of hCECs. Moreover, we also review the latest developments for the nanofabrication of such bio-instructive cell substrates.
\end{abstract}

Keywords: substrate topography; corneal endothelial cells; nanofabrication; cornea; corneal cell culture; topography; regenerative medicine; advanced cell culture substrates

\section{Introduction}

The cornea is a transparent tissue located in the anterior segment of the eye. This avascular tissue allows light to enter the eye and accounts for most of its refractive power [1]. It is composed of five layers (Figure 1): the epithelium, the Bowman's layer, the stroma, the Descemet's membrane and the endothelium. The corneal epithelium is the outermost layer and consists of a stratified sheet of epithelial cells residing on the Bowman's layer. The corneal stroma accounts for 80 to $90 \%$ of the total tissue volume and provides the cornea with mechanical strength. This layer is composed of highly structured collagen fibers and other extracellular matrix (ECM) proteins produced by the corneal keratocytes, which maintain the stromal homeostasis. The inner part of the cornea is composed of a monolayer of hexagonal endothelial cells that is in contact with the stroma through the Descemet's membrane (Figures 1 and 2), the latter being characterized by well-defined architecture, porosity and collagen fibrils dimension [2,3]. It is believed that a dual relationship exists between the Descemet's membrane and the corneal endothelium, where the pathophysiology of both of these parts can equally affect or be affected by the state of the other [3]. 
These (human) corneal endothelial cells (hCECs) play a crucial role in maintaining the corneal transparency by actively pumping ions and other metabolites from the stroma to the aqueous humor of the eye, consequently regulating the corneal hydration level. Unlike vascular endothelial cells, hCECs derive from the neural crest during development. In adults, hCECs are retained in a non-dividing G1 phase [4] and, thus, cannot contribute to the regeneration of this layer through cell division [5]. Corneal dystrophies, damage after surgery or infections can cause a loss of hCECs. The pathological profile of corneal endothelial disease is characterized by cornea edema and opacification. Between 2012 and 2013, about 200,000 corneal transplantations were performed worldwide, with an estimation of 12.7 million patients awaiting transplantation [6].

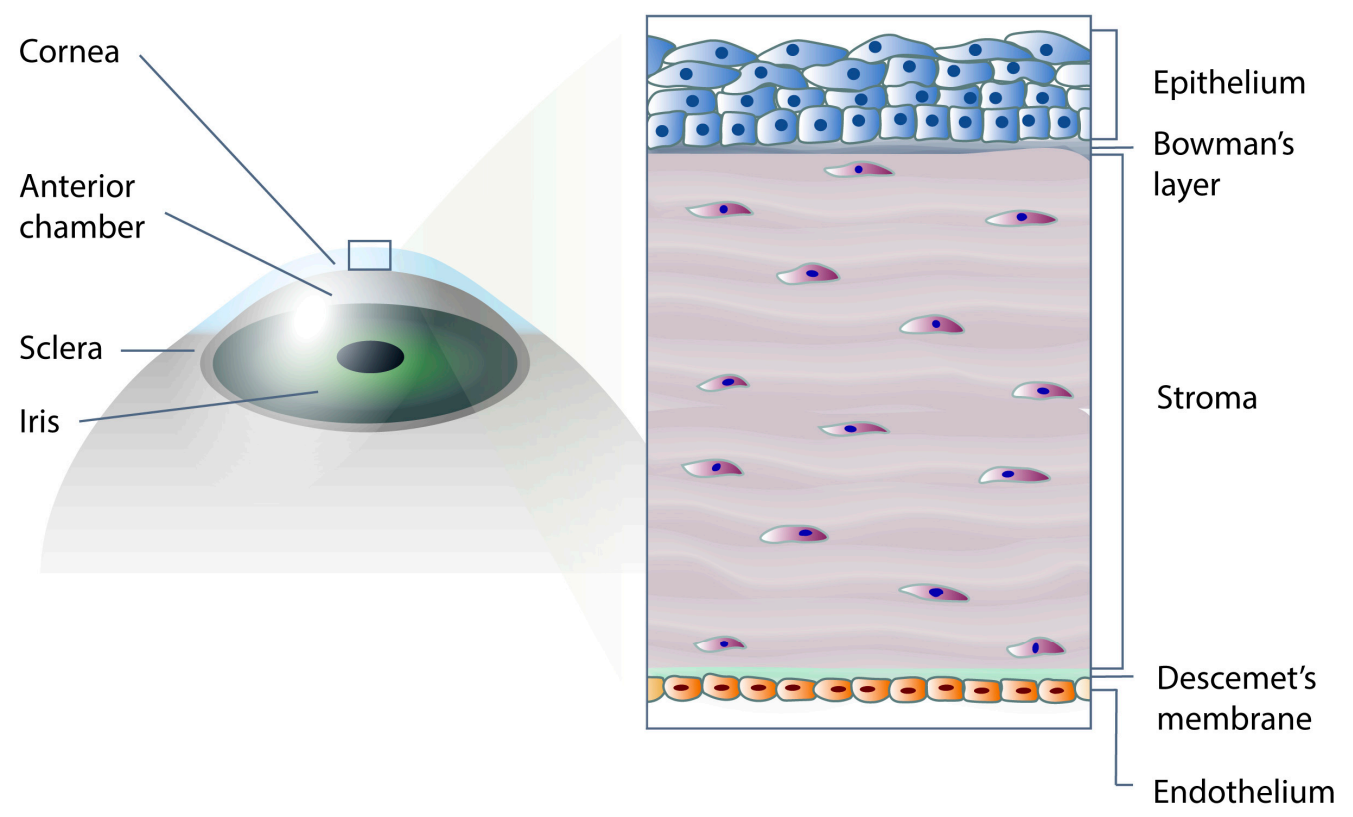

Figure 1. Anatomy of the cornea with schematic representation of its five main layers. Epithelial cells are indicated in blue, stromal keratocytes in purple and endothelial cells in orange.
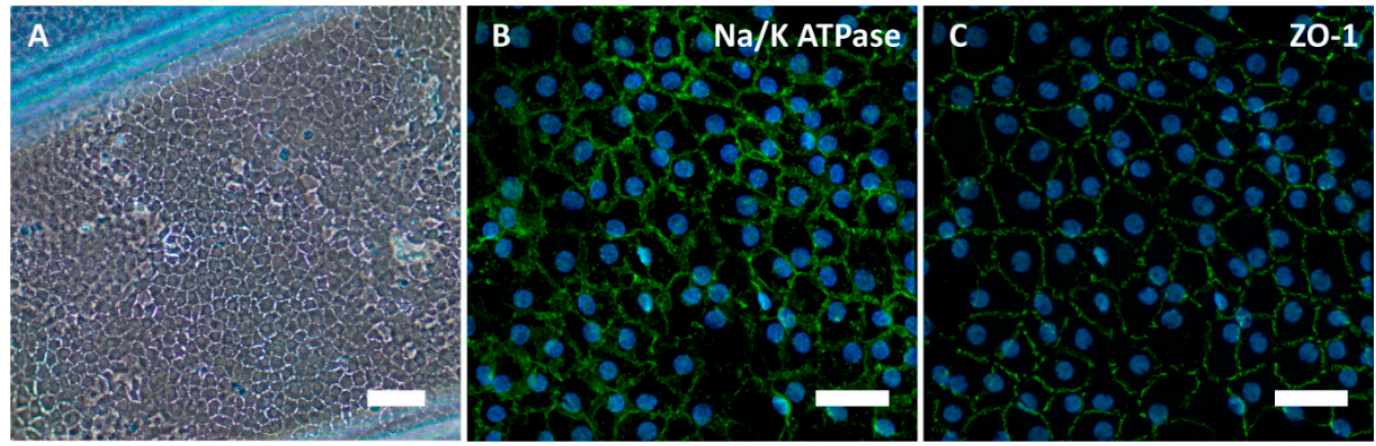

Figure 2. Human corneal endothelium biopsy analysis. Brightfield image of the typical hexagonal morphological pattern exhibited by human corneal endothelial cells (hCECs) (A); immunofluorescence analysis of native human corneal endothelium (B and C); cell nuclei were stained with Hoechst and are shown in blue. Functional marker $\mathrm{Na}^{+} / \mathrm{K}^{+}$-ATPase $(\mathbf{B})$ and tight junction marker ZO-1 (C) are shown in green. Scale bars: (A): $100 \mu \mathrm{m}$; (B) and (C): $50 \mu \mathrm{m}$.

Currently, the state-of-the-art therapy for corneal endothelial disease involves the selective replacement of the corneal endothelium with that of a donor [7]. However, only one donor cornea is available for every seventy patients in need [6]. The primary culture of hCECs is a promising alternative cell source to treat corneal endothelial disease [8], which would challenge the current one donor-one patient paradigm to make the therapy available for more patients. Despite hCECs being arrested in a non-proliferative state, it is 
possible to force their in vitro proliferation by culturing them with different basal media compositions, growth factors, such as fibroblast growth factor 2 or nerve growth factor, and other additives, such as ascorbic acid or calcium chloride [9]. Nonetheless, forcing hCECs to exit their quiescent state to enter a proliferative state by solely using biochemical factors is known to cause an undesired endothelial-to-mesenchymal transition resulting in a loss of function [10]. Despite the current efforts to optimize the primary expansion of hCECs, these cells tend to undergo phenotypical alterations already after two passages [11-13], suggesting that a longer culture period in a non-physiological environment leads to seemingly irreversible changes in cell behavior, therefore limiting the number of cells that can be derived from a donor cornea. Moreover, most successful cultures are from donors aged less than 40 years. Current standards for evaluating hCECs in vitro culture consist of assessing cell morphology and a panel of markers, such as $\mathrm{Na}^{+} / \mathrm{K}^{+}$-ATPase (an ion transporter assessed as functionality marker, Figure 2B), zona occludens-1 (ZO-1) (a tight junction protein, Figure 2C) and CD166 (a transmembrane protein ligand of CD6), none of which can be considered highly specific when analyzed independently. As an alternative to primary culture of hCECs, scientists have explored the differentiation of pluripotent stem cells to hCECs. Nevertheless, such differentiation protocols are still at an early developmental stage and need further improvements to prove that the genotype, phenotype and functionality of the differentiated cells resembles that of native hCECs [14-16]. Overall, the challenges associated with the primary culture of hCECs remain a barrier to their therapeutic application. Thus, there is a need for more advanced approaches that perhaps combine biophysical and biochemical factors in order to better control hCECs' phenotype over a prolonged period of time. Novel bioengineering tools have the potential to generate more defined and more physiological cell culture conditions also for hCECs.

To support the expansion and differentiation of cells in vitro, advanced, bioengineered cell culture substrates have been increasingly employed as a means to mimic biophysical cues that are originally present in native ECM environments [17-19]. These can be obtained by altering substrate features, such as stiffness, wettability, surface energy and topography through suitable fabrication and surface modification processes.

Micrometer scale and nanometer scale topographies' (microtopographies and nanotopographies') structures on cell culture surfaces have been shown to modulate cell behavior, for example by increasing cell adhesion, proliferation, migration, survival, differentiation and phenotype maintenance in many applications [17,19-22]. The addition of instructive topographies on cell culture scaffolds could, therefore, provide significant advantages compared to conventional flat (smooth) 2D substrates, as the first can offer biophysical cues that more closely replicate those present in the native ECM. Surface topographies have already been shown to modulate mesenchymal-to-endothelial/epithelial transition [23-26] and vice versa [27-30] in several others applications. However, research focusing on the interaction between hCECs and surface topography of the culture substrate remains relatively less explored compared to other (corneal) cell types, despite the fact that growing evidence (as reported in the next sections as well as from preliminary work by our group) is showing that subcellular topographies can also have a significant impact on hCECs' expansion and differentiation. In addition, although systematic data on how a defined microenvironment can be used to better guide corneal endothelial cells are essential to design/improve future studies, these are not yet available.

In this review, we briefly describe the range of nanofabrication techniques that can potentially be used to create well-defined cellular or subcellular topographic features for the culture of primary hCECs. We also summarize current knowledge and understanding of the effect of substrate topography on hCEC responses based on the current literature. This information will provide a comprehensive and concise overview of the current state-ofthe-art in bio-instructive nanotopographies for hCECs that will help the readers to design their own studies in the field of corneal endothelial regenerative medicine. 


\section{Nanofabrication Techniques to Design Instructive Cell Substrates}

A systematic study on the effect of subcellular topographies was so far difficult to realize also due to the complexity and high costs to produce large-scale nanopatterned areas for extensive cell studies. However, to gain a better understanding of the tools available to conduct such assays with hCECs, a methodic description of the corresponding nanofabrication techniques is essential.

Some of the current advanced nanofabrication techniques that have demonstrated to generate instructive cell substrates [31] are shown in Figure 3. Recapitulating key architectural features of the Descemet's membrane could be one of the most effective approaches for controlling hCECs expansion and phenotype in vitro. Nevertheless, fabricating multiscale and hierarchical structures with a precise control over porosity, fiber diameter and the overlaying hexagonal honeycomb feature, as in in vivo corneas, is challenging to achieve by a single technique and would likely require a combination of multiple nanofabrication techniques, some of which have not been widely employed in this field.

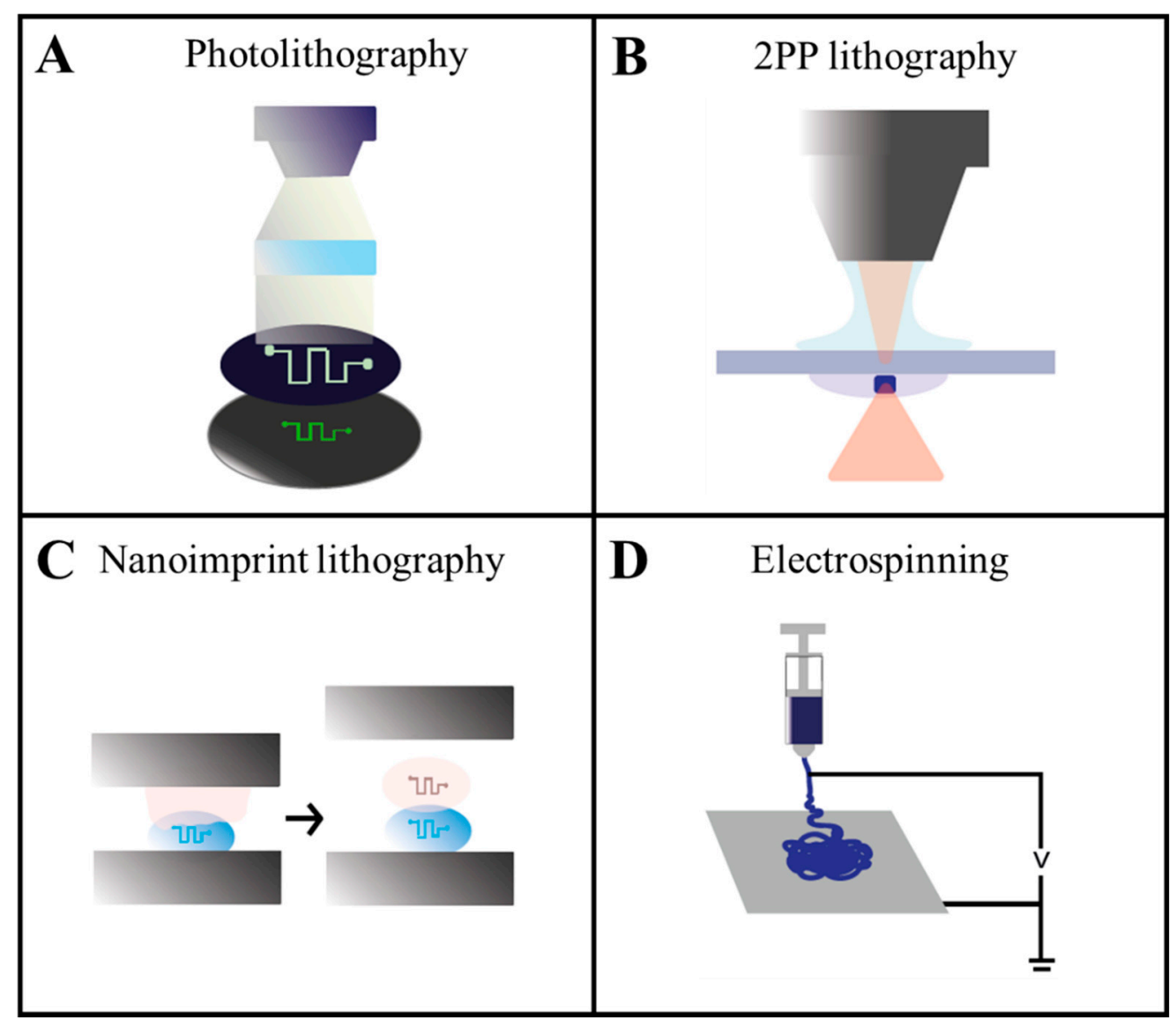

Figure 3. Examples of advanced fabrication tools that can be used for producing bio-instructive substrates for the culture of hCECs. (A) Photolithography for transferring a pattern into a photosensitive material. A photoresist is selectively exposed to UV light through a partially light-blocking photomask placed between the UV source and the resist; (B) 3D direct laser writing technique based on two-photon polymerization (2PP) lithography. This technique can generate 3D structures from photosensitive materials with resolutions $<100 \mathrm{~nm}$; (C) nanoimprint lithography. Surface features are transferred onto a polymer material through a mold (stamp) by means of heat or UV light; (D) electrospinning for producing continuous nanofibers. A high-voltage electric field is applied between a needle (connected to a polymeric solution reservoir) and a collector on which polymeric nanofibers are attracted.

Various nanofabrication techniques that are already well established in the semiconductor and micro-electronics industry have been adopted and are constantly growing into the tissue engineering and regenerative medicine field [32]. Many of these techniques rely 
on conventional light-/photon- or particle radiation-based lithography mostly in polymeric "(photo)resists" [33,34], or the same/similar methods followed by a transfer of the lithographic pattern through etching or electroplating/galvanoforming. These techniques were not originally developed for biological applications, and the materials commonly used are not dedicated/designed biomaterials or in some cases even cytotoxic, therefore, an increasing body of work is being (and needs to be further) carried out to identify suitable biomaterials and fabrication procedures for biomedical applications. Additionally, nanolithographic "master" structures are typically too time consuming and costly concerning their (clean room) fabrication to be directly used as disposable culture substrates. Therefore, nanostructures for cell studies are usually created by copying/replicating the pattern(s) of the master into another material [33], directly or via an intermediate template. This replication can be achieved via several techniques, such as soft-lithography [35-37], nanoimprint lithography (NIL) (including hot-embossing/thermal NIL and UV/photo-NIL) [38] and (micro-)injection molding [39-41]. These processes enable not only the replication of structures onto more biocompatible or active materials, but also large-scale production at low cost. Table 1 shows representative studies that combine advanced nanofabrication methods and pattern replication techniques to obtain features $<1 \mu \mathrm{m}$, a size regime that is of specific interest for cell studies.

Recently, two-photon polymerization (2PP) lithography, the process of crosslinking photosensitive resins with a focused femtosecond laser beam, showed promising results for mimicking biologically relevant architecture with a possible feature size of $<100 \mathrm{~nm}$. In contrast to other fabrication techniques where substrate surfaces can be modified to obtain patterns consisting of simple grooves and ridges (also referred as to $2 \frac{1}{2} \mathrm{D}$ nanotexture-type structures), 2PP (laser) lithography allows us to create real 3D nanostructure, which can include, for instance, hollow spaces. The recent deployment of 2PP lithography for an increasing number of biological applications has in turn motivated further improvements of this technique and the development of novel biocompatible materials for new applications $[42,43]$. The recent advances achieved with this technique allowed the generation of tissue-like structures, such as Descemet's membrane [44], luminal walls of blood vessels [45], limbal stem cell niche [46], cardiac ECM [47] and other 3D biologically relevant models [48-50].

Apart from lithography techniques, electrospinning has had an enormous impact on regenerative medicine by producing structures that more closely mimic nanofibrous ECMs present in in vivo tissues [51,52]. Electrospun fibers have been investigated as promising scaffolds particularly to promote cell growth by mimicking native collagen fibrils in ECM [53,54] as well as mimicking interface tissues [55].

The combination of different patterns and structures can be of particular relevance for hCECs regeneration. For instance, overlaying nanofibrous topographies to hexagonal patterns represents a potential approach to mimic the Descemet's membrane/corneal endothelium interface. More recently, the combination of diverse manufacturing techniques for complex, hierarchical tissue constructs on multiple scales is gaining momentum, and these have been reviewed elsewhere [56]. For corneal applications, applying innovative post-processing techniques, such as microthermoforming [57-59], also opens new opportunities for such hierarchical cell-material constructs, which will help to construct tissue-mimicking grafts with even superior resolution and reliability. 
Table 1. Examples of fabrication methods to fabricate sub-micron features used in cell studies.

\begin{tabular}{|c|c|c|c|}
\hline Fabrication Method & Feature Dimension (nm) & Cell Type & Reference \\
\hline Electron beam lithography and solvent casting & $\begin{array}{l}\text { Width: } 20 \mathrm{~nm}-1 \mu \mathrm{m} \\
\text { Depth: } 5-350 \mathrm{~nm}\end{array}$ & Rat dermal fibroblasts & {$[60]$} \\
\hline \multirow{4}{*}{ Electron beam lithography and hot embossing } & Diameter: $35-120 \mathrm{~nm}$ & Primary human fibroblasts & [61] \\
\hline & $\begin{array}{l}\text { Diameter: } 120 \mathrm{~nm} \\
\text { Interval: } 300 \mathrm{~nm} \\
\text { Height: } 100 \mathrm{~nm}\end{array}$ & $\begin{array}{l}\text { Human osteoprogenitor } \\
\text { and mesenchymal } \\
\text { stem cells }\end{array}$ & [62] \\
\hline & $\begin{array}{l}\text { Diameter: } 120 \mathrm{~nm} \\
\text { Interval: } 300 \mathrm{~nm} \\
\text { Depth: } 100 \mathrm{~nm}\end{array}$ & $\begin{array}{l}\text { Human mesenchymal } \\
\text { stem cells }\end{array}$ & [63] \\
\hline & $\begin{array}{l}\text { Diameter: } 35-120 \mathrm{~nm} \\
\text { Interval: } 100-300 \mathrm{~nm}\end{array}$ & $\begin{array}{l}\text { Human fibroblasts and } \\
\text { rat epitenon }\end{array}$ & [64] \\
\hline Photolithography and soft lithography & $\begin{array}{l}\text { Diameter: } 1 \mu \mathrm{m} \\
\text { Interval: } 600 \mathrm{~nm} \\
\text { Height: } 800 \mathrm{~nm}\end{array}$ & Mouse 3T3 fibroblasts & [65] \\
\hline $\begin{array}{c}\text { Interference lithography and deep reactive } \\
\text { ion etching }\end{array}$ & $\begin{array}{l}\text { Pitch: } 230 \mathrm{~nm} \\
\text { Height: } 50-600 \mathrm{~nm}\end{array}$ & Human foreskin fibroblasts & {$[66]$} \\
\hline $\begin{array}{c}\text { Interference lithography and nanoimprint } \\
\text { lithography }\end{array}$ & $\begin{array}{l}\text { Width: } 200 \mathrm{~nm} \\
\text { Interval: } 700 \mathrm{~nm}\end{array}$ & Human osteoblasts & [67] \\
\hline Nanoimprint lithography & $\begin{array}{l}\text { Pitch: } 420-800 \mathrm{~nm} \\
\text { Height: } 0-350 \mathrm{~nm}\end{array}$ & Murine preosteoblasts & {$[68]$} \\
\hline
\end{tabular}

\section{The Impact of Bio-Instructive Nanosubstrates for Culture on Corneal Endothelial Cells}

Intuitively, recreating the native Descemet's membrane structure is one of the most effective strategies to generate nanotopographies that can provide essential biophysical cues for the expansion of endothelial cells and maintenance of their phenotype. Since a direct replication of the native tissue, for instance via polymer casting on ex vivo tissue, could be technically complex to accomplish, Gutermuth and coworkers recreated Descemet's membrane-like topographies by a two-step process [44]. Firstly, rabbit Descemet's membrane topography was obtained by peeling and decellularization using ethylenediaminetetraacetic acid (EDTA) and subsequently scanned using confocal microscopy; this process highlighted the hexagonal structure of the Descemet's membrane with irregularly shaped honeycomb features having maximum depressions of $1 \mu \mathrm{m}$ and lateral size of 20 $\mu \mathrm{m}$. These topographical data were, thereafter, used to fabricate polydimethylsiloxane (PDMS) substrates with micro- and nanofeatures by two-photon lithography followed by soft-lithography. In this study, the authors demonstrated that human mesenchymal stromal cells (hMSCs), isolated from skin, could be differentiated towards an endothelial phenotype when cultured on such Descemet's membrane-like substrates using Dulbecco Modified Eagle Medium with $4.5 \mathrm{~g} / \mathrm{L}$ glucose, glutamine without pyruvate (DMEM) supplemented with fetal bovine serum. These cells were able to grow in a confluent monolayer, exhibiting the characteristic polygonal morphology of hCECs, in contrast to the fibroblastic morphology typical of MSCs. The cells cultured on Descemet's membrane replicas also expressed key markers of hCECs such as ZO- $1, \mathrm{Na}^{+} / \mathrm{K}^{+}$-ATPase, both at protein and mRNA level. The additional use of collagen coating on PDMS Descemet's membrane-like structures (collagen also supports hCECs in the native Descemet's membrane) induced further expression of hCEC-specific markers such as COL-8A2 and PITX2, therefore showing enhanced control over the cell fate. The possibility to efficiently switch from mesenchymal to endothelial-like cell phenotype using physical factors underlines the correlation of cell phenotype with the physicochemical microenvironment. Such phenotypical transition caused by nanotopographies can be considered remarkable if compared to the opposing undesired endothelial-to-mesenchymal transition generally occurring when attempting to expand primary hCECs on conventional 2D cell culture substrates. In clinical applications, the reversal from a pathological to a physiological hCECs phenotype is also observed in procedures such as Descemet's membrane transfer (DMT) [69], where a replacement of the Descemet's membrane is sufficient to induce the regeneration of host hCECs in vivo, 
and partially in descemetorhexis, without endothelial keratoplasty (DWEK), where the complete removal of a compromised ECM environment can also induce self-regeneration of a functional endothelium even without implantation of a new graft [70].

Similar to the hexagonal lattice of the Descemet's membrane, collagen nanofibers constituting the native ECM (Figure 4) are also considered for delivering essential biophysical cues that control corneal endothelial cell phenotype.

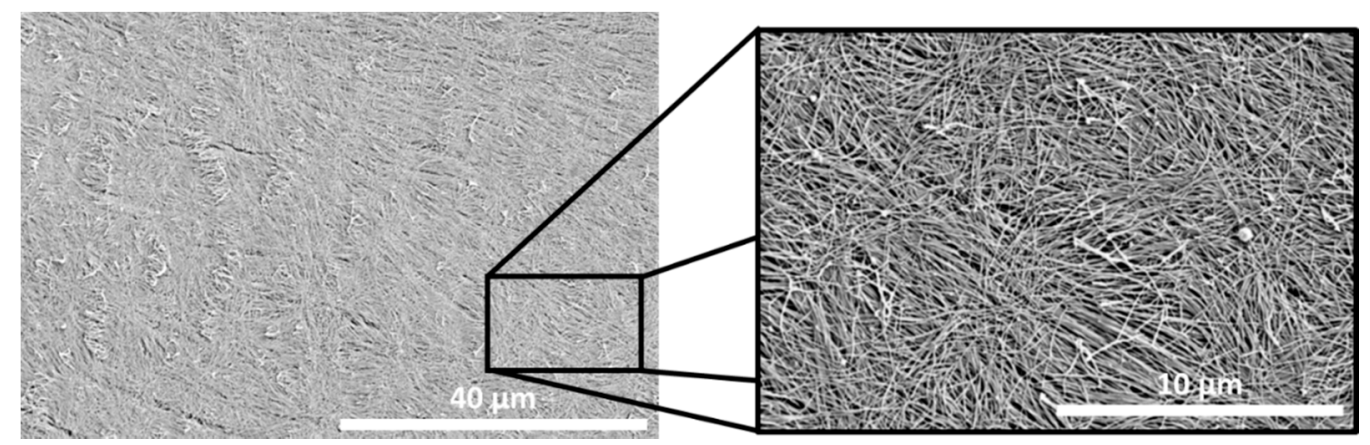

Figure 4. Scanning electron microscope (SEM) images of the human Descemet's membrane obtained by decellularization of the corneal endothelium.

To mimic the nanofibrillary contact guidance of native Descemet's membranes, instructive cell substrates can be produced by electrospinning using different materials. The Fuchsluger group proposed synthetic blends composed of poly(glycerol sebacate) and poly(e-caprolactone) (PGS/PCL) as nanofibrous scaffolds for the culture of corneal endothelial cells [71,72]. The scaffolds had elastic moduli in the same order of magnitude of native corneas. In these studies, a weight ratio of 4:1 parts of PGS with respect to PCL showed the best performances in terms of reaching confluence and exhibiting typical hCEC morphology. The scaffolds were made of aligned fibers with diameters between 200 and $500 \mathrm{~nm}$. Such dimensions were reported to improve cell response when compared to fibers with thickness in the micrometer range [73], confirming the efficacy of nanotopographies for hCECs. While the aligned fibers of these scaffolds induced immortalized hCECs (HCEC-12) to align along their main axis, the authors reported the eventual formation of a confluent cell monolayer with typical hexagonal pattern. Cyto- and immune-compatibility was assessed by studying the interaction of the scaffolds with peripheral blood mononuclear cells and polymorphonuclear leukocytes. Similarly, Kruse and coworkers also investigated the cytocompatibility of electrospun scaffolds made of poly(methyl-methacrylate) (PMMA), poly(lactic-co-glycolic acid) (PLGA) and PCL [74]. Generally, PMMA electrospun meshes exhibited high cytotoxicity, while both PCL and PLGA showed good levels of biocompatibility. Regarding the topographical features, although keeping equal fabrication parameters for the different materials, differences in fiber diameter and interstitial spaces were noticed. Cells preserved their normal morphology only on smaller fibers with smaller interstitial space, which was obtained with PLGA although perfect cellular monolayers could not be generated with any of the materials tested.

In another study, monolayers of the human corneal endothelial cell line B4G12 could be successfully formed using blends of nanofibrous structures made of silk fibroin and poly(Llactic acid-co-E-caprolactone) (P(LLA-CL)) [75]. The authors stated that the combination of natural and synthetic materials offered by silk:(P(LLA-CL)) constructs could provide both biocompatibility and mechanical properties necessary for the culture of endothelial cells. This study evaluated different parameters such as cell adherence, proliferation and gene expression as well as light transmittance, identifying 25:75 as the optimal ratio of SF:P(LLA-CL) for the culture of corneal endothelial cells.

Yim's group extensively studied bio-instructive substrates replicating features such as pillars and wells of various dimensions in different materials (Figure 5) [76-81]. In particular, they were able to improve not only hCECs culture but also to recreate a disease 
model such as Fuchs' endothelial dystrophy by using these topographies (Figure 5B), which is the main indication for endothelial keratoplasty (surgery) worldwide and for which currently no functional in vitro models are available [80]. Interestingly, the use of substrates with higher pillar density and with larger features $(>10 \mu \mathrm{m})$ was shown to prevent monolayer formation and induce Fuchs' endothelial dystrophy conditions (i.e., mimicking guttata), stressing the importance of sub-cellular features for physiological hCEC expansion and phenotype.

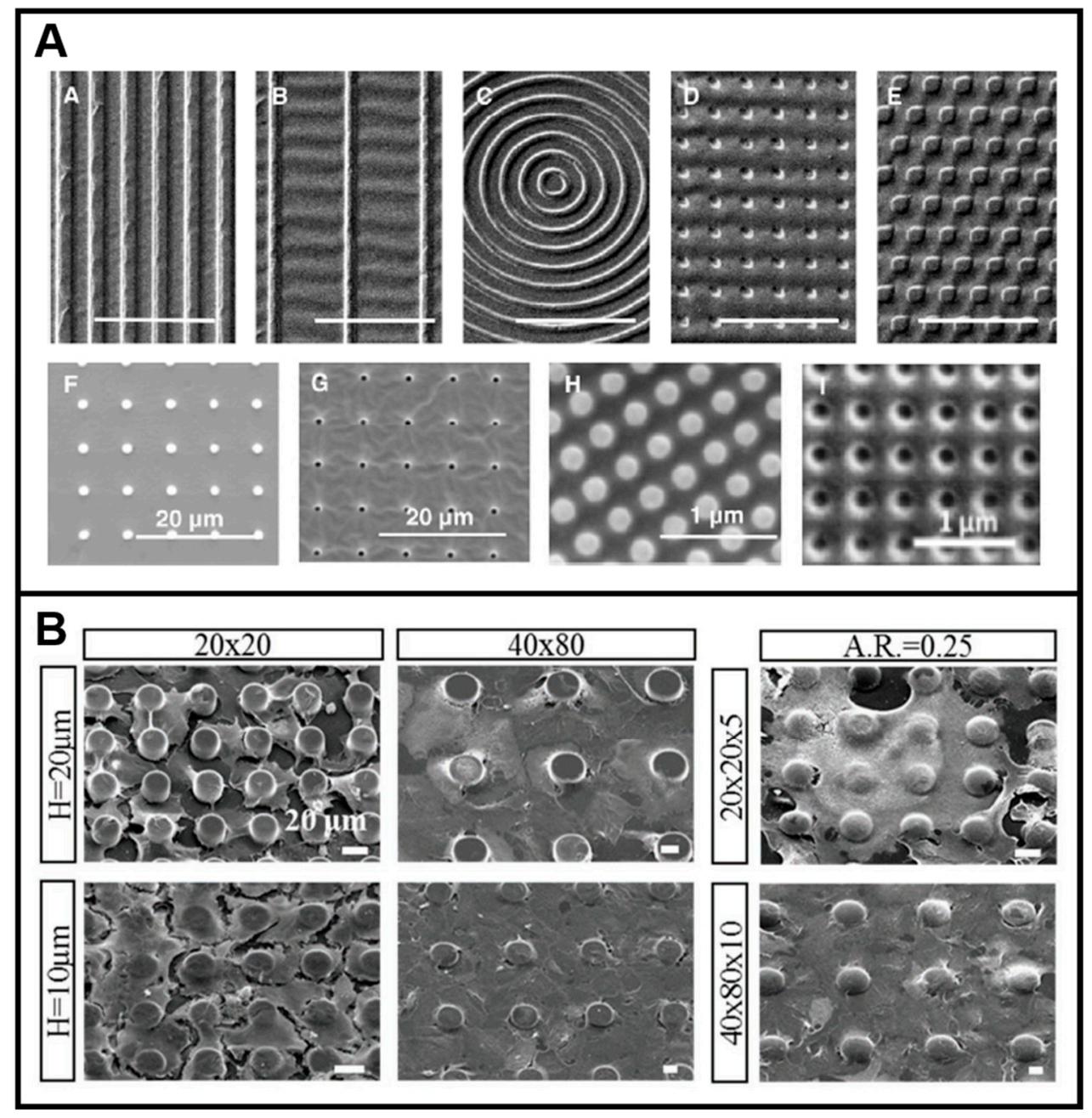

Figure 5. Examples of substrate topographies used for the culture of hCECs. Nanopillars (E,F,H in top image) and nanowells (D,G,E,I in top image) were demonstrated to better induce hCECs expansion and maintenance of their phenotype compared to other topographies (A-C in top image) (A), while patterns with larger dimensions can be used for modelling disease of hCECs such as Fuch's endothelial dystrophy (B). Scale bars: $20 \mu \mathrm{m}$ unless specified. Reproduced from [77] (A) and [80] (B).

Regarding the influence of particular patterns on hCECs expansion and phenotype, nanopillars and nanowells showed improved guidance compared to other nanopatterns [76,77]. Pillars patterned on gel-methacrylate (GelMA) substrates induced enhanced ZO-1 expression and morphological parameters according to whether they were arranged in a square or hexagonal pattern [81]. The authors also showed that the expression of ZO-1 could be retained upon removal of the biophysical cues, i.e., when cells were subsequently cultured again on conventional tissue culture plastic, indicating a memory effect of cells after exposure to topographical cues [79].

Nanotopographies can also be used to generate carriers for tissue engineered corneal endothelium, therefore not only for ensuring hCECs expansion in vitro but also for main- 
taining the hCECs phenotype upon transplantation. In a study by Kim and coworkers, nanoporous (pore size $<200 \mathrm{~nm}$ diameter) silk fibroin films were explored as a carrier for rabbit corneal endothelial cells [82]. Although this study was not focused on comparing different nanofeatures but assessed the effect of sericin content in the films, it demonstrated that this nanomaterial supports cell attachment and morphology well, as well as expression of ZO-1 and $\mathrm{Na}^{+} / \mathrm{K}^{+}$-ATPase both at the mRNA and protein level.

\section{Conclusions and Future Directions}

Effective cell therapy and regenerative medicine approaches require hCECs to form confluent monolayers, while maintaining their original phenotype. To induce the formation of a functional, confluent hCECs monolayer, there is a limitation on the features and dimensions of topographies that can be used. In particular, topographical features (both lateral size and height), with dimensions comparable to or larger than the cellular size (i.e., $\geq 2-5 \mu \mathrm{m}$ ), can hinder the formation of a continuous layer of cells and steer cells away from the corneal endothelium phenotype. For this reason, subcellular (nano-)topographical patterns have demonstrated better support for the physiological hCECs' phenotype over micro-topographical patterns. In light of the studies reviewed in this work, it is evident that nanotopographies are a potential technology to further support primary hCEC expansion and, therefore, increase the pool of cells suitable for corneal endothelial regenerative therapy, while larger micro-topographies could provide avenues for modelling hCEC disease.

While nanofabrication techniques enabled the generation of improved substrates for hCECs culture, further improvements are required. For instance, imprinting nanotopographies on electrospun fiber meshes by fiber-level patterning results in hierarchically structured substrates, which could improve current protocols for hCECs regeneration [83]. Moreover, the combination of multiple nanotechnologies that allows the superimposition of porosity onto nanopatterns can also generate new strategies for recapitulating the native endothelial environment and facilitate nutrient, water, ion and metabolite transport of tissue engineered corneal endothelium. Creating controlled porosity on substrates is possible by various methods, such as photolithography and ion-track technology [84], the latter being already implemented to fabricate porous polycarbonate membranes, which are commercialized for cell culture applications [85]. On the other hand, self-assembly techniques such as water droplet-assisted methods [86] including breath figure [87] and phase separation methods [88] can still be considered as alternative to lithography techniques.

The combination of biomaterials, fabrication techniques and specific patterns could impact on the overall biophysical and biological performances [89-91]. Biomechanical properties, biodegradability as well as ions and nutrient diffusion, for instance, are all important factors needing careful consideration when selecting suitable materials and fabrication techniques for translational applications. Moreover, major steps for the design of future studies also include the optimization of surface chemistry and substrate stiffness.

Thus far, nanotopographies demonstrated efficacy towards inducing corneal endothelial regeneration; however, new (combinations) of existing nanotechnology offer the potential to provide additional tools for further advancing this field. The studies reported in this review can, therefore, provide basic insights to design novel studies for hCECs regeneration and eventually provide therapeutic solutions for corneal endothelium dysfunctions.

Author Contributions: Conceptualization: N.F.; methodology, writing—original draft preparation, resources: N.F., G.S. and P.C.; writing-review and editing: N.F., G.S., P.C., S.G., R.T., V.L.S.L., M.M.D. and R.M.M.A.N.; supervision, resources: S.G., R.T., V.L.S.L., M.M.D. and R.M.M.A.N.; project administration and funding acquisition: S.G. All authors have read and agreed to the published version of the manuscript.

Funding: This research was part of BM3.02 EyeSciTe and performed under the framework of Chemelot InSciTe.

Institutional Review Board Statement: Not applicable. 
Informed Consent Statement: Not applicable.

Data Availability Statement: Data sharing not applicable.

Conflicts of Interest: The authors declare no conflict of interest.

\section{References}

1. Patel, S.; Alió, J.L.; Pérez-Santonja, J.J. Refractive Index Change in Bovine and Human Corneal Stroma before and after LASIK: A Study of Untreated and Re-Treated Corneas Implicating Stromal Hydration. Investig. Ophthalmol. Vis. Sci. 2004, 45, 3523-3530. [CrossRef] [PubMed]

2. de Oliveira, R.C.; Wilson, S.E. Descemet's Membrane Development, Structure, Function and Regeneration. Exp. Eye Res. 2020, 197, 108090. [CrossRef] [PubMed]

3. Ali, M.; Raghunathan, V.K.; Li, J.Y.; Murphy, C.J.; Thomasy, S.M. Biomechanical Relationships between the Corneal Endothelium and Descemet's Membrane. Exp. Eye Res. 2016, 152, 57-70. [CrossRef] [PubMed]

4. Lwigale, P.Y. Corneal Development: Different Cells from a Common Progenitor, 1st ed.; Elsevier Inc.: Amsterdam, The Netherlands, 2015; Volume 134, pp. 43-59. [CrossRef]

5. Joyce, N.C. Proliferative Capacity of Corneal Endothelial Cells. Exp. Eye Res. 2012, 95, 16-23. [CrossRef] [PubMed]

6. Gain, P.; Jullienne, R.; He, Z.; Aldossary, M.; Acquart, S.; Cognasse, F.; Thuret, G. Global Survey of Corneal Transplantation and Eye Banking. JAMA Ophthalmol. 2016, 134, 167-173. [CrossRef] [PubMed]

7. Price, M.O.; Mehta, J.S.; Jurkunas, U.V.; Price, F.W. Corneal Endothelial Dysfunction: Evolving Understanding and Treatment Options. Prog. Retin. Eye Res. 2020. [CrossRef]

8. Mimura, T.; Yamagami, S.; Amano, S. Corneal Endothelial Regeneration and Tissue Engineering. Prog. Retin. Eye Res. 2013, 35, 1-17. [CrossRef]

9. Peh, G.S.L.; Beuerman, R.W.; Colman, A.; Tan, D.T.; Mehta, J.S. Human Corneal Endothelial Cell Expansion for Corneal Endothelium Transplantation: An Overview. Transplantation 2011, 91, 811-819. [CrossRef]

10. Roy, O.; Leclerc, V.B.; Bourget, J.M.; Thériault, M.; Proulx, S. Understanding the Process of Corneal Endothelial Morphological Change in Vitro. Investig. Ophthalmol. Vis. Sci. 2015, 56, 1228-1237. [CrossRef]

11. Kinoshita, S.; Koizumi, N.; Ueno, M.; Okumura, N.; Imai, K.; Tanaka, H.; Yamamoto, Y.; Nakamura, T.; Inatomi, T.; Bush, J.; et al. Injection of Cultured Cells with a ROCK Inhibitor for Bullous Keratopathy. N. Engl. J. Med. 2018, 378, 995-1003. [CrossRef]

12. Peh, G.S.L.; Chng, Z.; Ang, H.P.; Cheng, T.Y.D.; Adnan, K.; Seah, X.Y.; George, B.L.; Toh, K.P.; Tan, D.T.; Yam, G.H.F.; et al. Propagation of Human Corneal Endothelial Cells: A Novel Dual Media Approach. Cell Transpl. 2015, 24, 287-304. [CrossRef] [PubMed]

13. Frausto, R.F.; Swamy, V.S.; Peh, G.S.L.; Boere, P.M.; Hanser, E.M.; Chung, D.D.; George, B.L.; Morselli, M.; Kao, L.; Azimov, R.; et al. Phenotypic and Functional Characterization of Corneal Endothelial Cells during in Vitro Expansion. Sci. Rep. 2020, 10, 7402. [CrossRef] [PubMed]

14. Wagoner, M.D.; Bohrer, L.R.; Aldrich, B.T.; Greiner, M.A.; Mullins, R.F.; Worthington, K.S.; Tucker, B.A.; Wiley, L.A. Feeder-Free Differentiation of Cells Exhibiting Characteristics of Corneal Endothelium from Human Induced Pluripotent Stem Cells. Biol. Open 2018, 7, 1-10. [CrossRef] [PubMed]

15. Zhao, J.J.; Afshari, N.A. Generation of Human Corneal Endothelial Cells via In Vitro Ocular Lineage Restriction of Pluripotent Stem Cells. Investig. Ophthalmol. Vis. Sci. 2016, 57, 6878-6884. [CrossRef] [PubMed]

16. McCabe, K.L.; Kunzevitzky, N.J.; Chiswell, B.P.; Xia, X.; Goldberg, J.L.; Lanza, R. Efficient Generation of Human Embryonic Stem Cell-Derived Corneal Endothelial Cells by Directed Differentiation. PLoS ONE 2015, 10, e0145266. [CrossRef]

17. Stevens, M.M.; George, J.H. Exploring and Engineering the Cell Surface Interface. Science 2005, 310, 1135-1138. [CrossRef]

18. Lee, J.; Cuddihy, M.J.; Kotov, N.A. Three-Dimensional Cell Culture Matrices: State of the Art. Tissue Eng. Part B Rev. 2008, 14, 61-86. [CrossRef]

19. Mirbagheri, M.; Adibnia, V.; Hughes, B.R.; Waldman, S.D.; Banquy, X.; Hwang, D.K. Advanced Cell Culture Platforms: A Growing Quest for Emulating Natural Tissues. Mater. Horiz. 2019, 6, 45-71. [CrossRef]

20. Kulangara, K.; Leong, K.W. Substrate Topography Shapes Cell Function. Soft Matter 2009, 5, 4072-4076. [CrossRef]

21. Bettinger, C.J.; Langer, R.; Borenstein, J.T. Engineering Substrate Topography at the Micro- and Nanoscale to Control Cell Function. Angew. Chem. Int. Ed. 2009, 48, 5406-5415. [CrossRef]

22. Genova, T.; Roato, I.; Carossa, M.; Motta, C.; Cavagnetto, D.; Mussano, F. Advances on Bone Substitutes through 3d Bioprinting. Int. J. Mol. Sci. 2020, 21, 12. [CrossRef] [PubMed]

23. Wang, Z.; Xia, F.; Labib, M.; Ahmadi, M.; Chen, H.; Das, J.; Sargent, E.H.; Kelley, S.O.; Ahmed, S.U. Nanostructured Architectures Promote the Mesenchymal-Epithelial Transition for Invasive Cells. ACS Nano 2020, 14, 5324-5336. [CrossRef] [PubMed]

24. Li, J.; Kwiatkowska, B.; Lu, H.; Voglsta, M.; Ueda, E.; Grunze, M.; Sleeman, J.; Levkin, P.A.; Nazarenko, I. Collaborative Action of Surface Chemistry and Topography in the Regulation of Mesenchymal and Epithelial Markers and the Shape of Cancer Cells. ACS Appl. Mater. Interfaces 2016, 8, 28554-28565. [CrossRef] [PubMed]

25. Barui, A.; Chowdhury, F.; Pandit, A.; Datta, P. Biomaterials Rerouting Mesenchymal Stem Cell Trajectory towards Epithelial Lineage by Engineering Cellular Niche. Biomaterials 2018, 156, 28-44. [CrossRef] 
26. Downing, T.L.; Soto, J.; Morez, C.; Houssin, T.; Fritz, A.; Yuan, F.; Chu, J.; Patel, S.; Schaffer, D.V.; Li, S. Biophysical Regulation of Epigenetic State and Cell Reprogramming. Nat. Mater. 2013, 12, 1154-1162. [CrossRef]

27. Yi, B.; Shen, Y.; Tang, H.; Wang, X.; Zhang, Y. Acta Biomaterialia Stiffness of the Aligned Fibers Affects Structural and Functional Integrity of the Oriented Endothelial Cells. Acta Biomater. 2020, 108, 237-249. [CrossRef]

28. Nasrollahi, S.; Pathak, A. Topographic Confinement of Epithelial Clusters Induces Epithelial-to-Mesenchymal Transition in Compliant Matrices. Sci. Rep. 2016, 6, 18831. [CrossRef]

29. Saha, S.; Duan, X.; Wu, L.; Lo, P.; Chen, H.; Wang, Q. Electrospun Fibrous Scaffolds Promote Breast Cancer Cell Alignment and Epithelial-Mesenchymal Transition. Langmuir 2012, 28, 2028-2034. [CrossRef]

30. Xu, X.; Ma, L.; Wu, Y.; Tang, L. Micropillar-Based Culture Platform Induces Epithelial-Mesenchymal Transition in the Alveolar Epithelial Cell Line. J. Biomed. Mater. Res. Part A 2018, 3165-3174. [CrossRef]

31. Limongi, T.; Tirinato, L.; Pagliari, F.; Giugni, A.; Allione, M.; Perozziello, G.; Candeloro, P.; Di Fabrizio, E. Fabrication and Applications of Micro/Nanostructured Devices for Tissue Engineering. Nano-Micro Lett. 2017, 9, 1. [CrossRef]

32. Kim, H.N.; Jiao, A.; Hwang, N.S.; Kim, M.S.; Kang, D.H.; Kim, D.H.; Suh, K.Y. Nanotopography-Guided Tissue Engineering and Regenerative Medicine. Adv. Drug Deliv. Rev. 2013, 65, 536-558. [CrossRef] [PubMed]

33. Gates, B.D.; Xu, Q.; Stewart, M.; Ryan, D.; Willson, C.G.; Whitesides, G.M. New Approaches to Nanofabrication: Molding, Printing, and Other Techniques. Chem. Rev. 2005, 105, 1171-1196. [CrossRef] [PubMed]

34. Menon, R.; Patel, A.; Gil, D.; Smith, H.I. Maskless Lithography. Mater. Today 2005, 8, 26-33. [CrossRef]

35. Xia, Y.; Whitesides, G.M. Soft Lithography. Angew. Chem. Int. Ed. 1998, 37, 550-575. [CrossRef]

36. Xia, Y.; Rogers, J.A.; Paul, K.E.; Whitesides, G.M. Unconventional Methods for Fabricating and Patterning Nanostructures. Chem. Rev. 1999, 99, 1823-1848. [CrossRef]

37. Xia, Y.; Whitesides, G.M. Soft Lithography. Annu. Rev. Mater. Sci. 1998, 28, 153-184. [CrossRef]

38. Guo, L.J. Recent Progress in Nanoimprint Technology and Its Applications. J. Phys. D Appl. Phys. 2004, 37, R123-R141. [CrossRef]

39. Lantada, A.D.; Piotter, V.; Plewa, K.; Barié, N.; Guttmann, M.; Wissmann, M. Toward Mass Production of Microtextured Microdevices: Linking Rapid Prototyping with Microinjection Molding. Int. J. Adv. Manuf. Technol. 2015, 76, 1011-1020. [CrossRef]

40. Mondrinos, M.J.; Dembzynski, R.; Lu, L.; Byrapogu, V.K.C.; Wootton, D.M.; Lelkes, P.I.; Zhou, J. Porogen-Based Solid Freeform Fabrication of Polycaprolactone-Calcium Phosphate Scaffolds for Tissue Engineering. Biomaterials 2006, 27, 4399-4408. [CrossRef]

41. Choi, N.W.; Cabodi, M.; Held, B.; Gleghorn, J.P.; Bonassar, L.J.; Stroock, A.D. Microfluidic Scaffolds for Tissue Engineering. Nat. Mater. 2007, 6, 908-915. [CrossRef]

42. Nguyen, A.K.; Narayan, R.J. Two-Photon Polymerization for Biological Applications. Mater. Today 2017, 20, 314-322. [CrossRef]

43. Raimondi, M.T.; Eaton, S.M.; Nava, M.M.; Laganà, M.; Cerullo, G.; Osellame, R. Two-Photon Laser Polymerization: From Fundamentals to Biomedical Application in Tissue Engineering and Regenerative Medicine. J. Appl. Biomater. Funct. Mater. 2012, 10, 56-66. [CrossRef] [PubMed]

44. Gutermuth, A.; Maassen, J.; Harnisch, E.; Kuhlen, D.; Sauer-Budge, A.; Skazik-Voogt, C.; Engelmann, K. Descemet's Membrane Biomimetic Microtopography Differentiates Human Mesenchymal Stem Cells Into Corneal Endothelial-Like Cells. Cornea 2019, 38, 110-119. [CrossRef] [PubMed]

45. Cheng, D.; Jayne, R.K.; Tamborini, A.; Eyckmans, J.; White, A.E.; Chen, C.S. Studies of 3D Directed Cell Migration Enabled by Direct Laser Writing of Curved Wave Topography. Biofabrication 2019, 11, 21001. [CrossRef] [PubMed]

46. Prina, E.; Amer, M.H.; Sidney, L.; Tromayer, M.; Moore, J.; Liska, R.; Bertolin, M.; Ferrari, S.; Hopkinson, A.; Dua, H.; et al. Bioinspired Precision Engineering of Three-Dimensional Epithelial Stem Cell Microniches. Adv. Biosyst. 2020, 4, 2000016. [CrossRef] [PubMed]

47. Gao, L.; Kupfer, M.E.; Jung, J.P.; Yang, L.; Zhang, P.; Da Sie, Y.; Tran, Q.; Ajeti, V.; Freeman, B.T.; Fast, V.G.; et al. Myocardial Tissue Engineering with Cells Derived from Human-Induced Pluripotent Stem Cells and a Native-Like, High-Resolution, 3-Dimensionally Printed Scaffold. Circ. Res. 2017, 120, 1318-1325. [CrossRef]

48. Koroleva, A.; Gittard, S.; Schlie, S.; Deiwick, A.; Jockenhoevel, S.; Chichkov, B. Fabrication of Fibrin Scaffolds with Controlled Microscale Architecture by a Two-Photon Polymerization-Micromolding Technique. Biofabrication 2012, 4, 15001. [CrossRef]

49. Ovsianikov, A.; Malinauskas, M.; Schlie, S.; Chichkov, B.; Gittard, S.; Narayan, R.; Löbler, M.; Sternberg, K.; Schmitz, K.P.; Haverich, A. Three-Dimensional Laser Micro- and Nano-Structuring of Acrylated Poly(Ethylene Glycol) Materials and Evaluation of Their Cytoxicity for Tissue Engineering Applications. Acta Biomater. 2011, 7, 967-974. [CrossRef]

50. Ovsianikov, A.; Gruene, M.; Pflaum, M.; Koch, L.; Maiorana, F.; Wilhelmi, M.; Haverich, A.; Chichkov, B. Laser Printing of Cells into 3D Scaffolds. Biofabrication 2010, 2, 14104. [CrossRef]

51. Nair, L.S.; Bhattacharyya, S.; Laurencin, C.T. Development of Novel Tissue Engineering Scaffolds via Electrospinning. Expert Opin. Biol. Ther. 2004, 4, 659-668. [CrossRef]

52. Greiner, A.; Wendorff, J.H. Electrospinning: A Fascinating Method for the Preparation of Ultrathin Fibers. Angew. Chem. Int. Ed. 2007, 46, 5670-5703. [CrossRef] [PubMed]

53. Matthews, J.A.; Wnek, G.E.; Simpson, D.G.; Bowlin, G.L. Electrospinning of Collagen Nanofibers. Biomacromolecules 2002, 3, 232-238. [CrossRef] [PubMed]

54. Pham, Q.P.; Sharma, U.; Mikos, A.G. Electrospinning of Polymeric Nanofibers for Tissue Engineering Applications: A Review. Tissue Eng. 2006, 12, 1197-1211. [CrossRef] [PubMed] 
55. Yao, T.; Chen, H.; Samal, P.; Giselbrecht, S.; Baker, M.B.; Moroni, L. Self-Assembly of Electrospun Nanofibers into Gradient Honeycomb Structures. Mater. Des. 2019, 168, 107614. [CrossRef]

56. Dalton, P.D.; Woodfield, T.B.F.; Mironov, V.; Groll, J. Advances in Hybrid Fabrication toward Hierarchical Tissue Constructs. Adv. Sci. 2020, 7, 1902953. [CrossRef]

57. Giselbrecht, S.; Gietzelt, T.; Gottwald, E.; Trautmann, C.; Truckenmuller, R.; Weibezahn, K.F.; Welle, A. 3D Tissue Culture Substrates Produced by Microthermoforming of Pre-Processed Polymer Films. Biomed. Microdevices 2006, 8, 191-199. [CrossRef]

58. Truckenmüller, R.; Giselbrecht, S.; Escalante-Marun, M.; Groenendijk, M.; Papenburg, B.; Rivron, N.; Unadkat, H.; Saile, V.; Subramaniam, V.; Van Den Berg, A.; et al. Fabrication of Cell Container Arrays with Overlaid Surface Topographies. Biomed. Microdevices 2012, 14, 95-107. [CrossRef]

59. Truckenmüller, R.; Giselbrecht, S.; Rivron, N.; Gottwald, E.; Saile, V.; Van Den Berg, A.; Wessling, M.; Van Blitterswijk, C. Thermoforming of Film-Based Biomedical Microdevices. Adv. Mater. 2011, 23, 1311-1329. [CrossRef]

60. Loesberg, W.A.; te Riet, J.; van Delft, F.C.; Schon, P.; Figdor, C.G.; Speller, S.; van Loon, J.J.; Walboomers, X.F.; Jansen, J.A. The Threshold at Which Substrate Nanogroove Dimensions May Influence Fibroblast Alignment and Adhesion. Biomaterials 2007, 28, 3944-3951. [CrossRef]

61. Dalby, M.J.; Gadegaard, N.; Riehle, M.O.; Wilkinson, C.D.W.; Curtis, A.S.G. Investigating Filopodia Sensing Using Arrays of Defined Nano-Pits down to 35 Nm Diameter in Size. Int. J. Biochem. Cell Biol. 2004, 36, 2005-2015. [CrossRef]

62. Dalby, M.J.; Gadegaard, N.; Tare, R.; Andar, A.; Riehle, M.O.; Herzyk, P.; Wilkinson, C.D.W.; Oreffo, R.O.C. The Control of Human Mesenchymal Cell Differentiation Using Nanoscale Symmetry and Disorder. Nat. Mater. 2007, 6, 997-1003. [CrossRef] [PubMed]

63. McMurray, R.J.; Gadegaard, N.; Tsimbouri, P.M.; Burgess, K.V.; McNamara, L.E.; Tare, R.; Murawski, K.; Kingham, E.; Oreffo, R.O.C.; Dalby, M.J. Nanoscale Surfaces for the Long-Term Maintenance of Mesenchymal Stem Cell Phenotype and Multipotency. Nat. Mater. 2011, 10, 637-644. [CrossRef] [PubMed]

64. Curtis, A.S.G.; Gadegaard, N.; Dalby, M.J.; Riehle, M.O.; Wilkinson, C.D.W.; Aitchison, G. Cells React to Nanoscale Order and Symmetry in Their Surroundings. IEEE Trans. Nanobiosci. 2004, 3, 61-65. [CrossRef] [PubMed]

65. Tzvetkova-Chevolleau, T.; Stéphanou, A.; Fuard, D.; Ohayon, J.; Schiavone, P.; Tracqui, P. The Motility of Normal and Cancer Cells in Response to the Combined Influence of the Substrate Rigidity and Anisotropic Microstructure. Biomaterials 2008, 29, 1541-1551. [CrossRef] [PubMed]

66. Choi, C.H.; Hagvall, S.H.; Wu, B.M.; Dunn, J.C.Y.; Beygui, R.E.; Kim, C.J. Cell Interaction with Three-Dimensional Sharp-Tip Nanotopography. Biomaterials 2007, 28, 1672-1679. [CrossRef] [PubMed]

67. Eunhye, K.; Jinwoo, L.; Sungmo, A.; Heonsu, J.; Kyuback, L. Cell Culture over Nanopatterned Surface Fabricated by Holographic Lithography and Nanoimprint Lithography. In Proceedings of the 2008 3rd IEEE International Conference on Nano/Micro Engineered and Molecular Systems, Sanya, China, 6-9 January 2008; pp. 725-728. [CrossRef]

68. Sun, J.; Ding, Y.; Lin, N.J.; Zhou, J.; Ro, H.; Soles, C.L.; Cicerone, M.T.; Lin-Gibson, S. Exploring Cellular Contact Guidance Using Gradient Nanogratings. Biomacromolecules 2010, 11, 3067-3072. [CrossRef]

69. Soh, Y.Q.; Mehta, J.S. Regenerative Therapy for Fuchs Endothelial Corneal Dystrophy. Cornea 2018, 37, 523-527. [CrossRef]

70. Walckling, M.; Waterstradt, R.; Baltrusch, S. Collagen Remodeling Plays a Pivotal Role in Endothelial Corneal Dystrophies. Investig. Ophthalmol. Vis. Sci. 2020, 61, 1-15. [CrossRef]

71. Salehi, S.; Czugala, M.; Stafiej, P.; Fathi, M.; Bahners, T.; Gutmann, J.S.; Singer, B.B.; Fuchsluger, T.A. Poly (Glycerol Sebacate)-Poly ( $\varepsilon$-Caprolactone) Blend Nanofibrous Scaffold as Intrinsic Bio- and Immunocompatible System for Corneal Repair. Acta Biomater. 2017, 50, 370-380. [CrossRef]

72. Salehi, S.; Bahners, T.; Gutmann, J.S.; Gao, S.L.; Mäder, E.; Fuchsluger, T.A. Characterization of Structural, Mechanical and Nano-Mechanical Properties of Electrospun PGS/PCL Fibers. RSC Adv. 2014, 4, 16951-16957. [CrossRef]

73. Saino, E.; Focarete, M.L.; Gualandi, C.; Emanuele, E.; Cornaglia, A.I.; Imbriani, M.; Visai, L. Effect of Electrospun Fiber Diameter and Alignment on Macrophage Activation and Secretion of Proinflammatory Cytokines and Chemokines. Biomacromolecules 2011, 12, 1900-1911. [CrossRef] [PubMed]

74. Kruse, M.; Walter, P.; Bauer, B.; Rütten, S.; Schaefer, K.; Plange, N.; Gries, T.; Jockenhoevel, S.; Fuest, M. Electro-Spun Membranes as Scaffolds for Human Corneal Endothelial Cells. Curr. Eye Res. 2018, 43, 1-11. [CrossRef] [PubMed]

75. Chen, J.; Yan, C.; Zhu, M.; Yao, Q.; Shao, C.; Lu, W.; Wang, J.; Mo, X.; Gu, P.; Fu, Y.; et al. Electrospun Nanofibrous SF/P(LLA-CL) Membrane: A Potential Substratum for Endothelial Keratoplasty. Int. J. Nanomed. 2015, 10, 3337-3350. [CrossRef]

76. Chua, J.; Liew, L.; Yim, E. Cultivation of Human Microvascular Endothelial Cells on Topographical Substrates to Mimic the Human Corneal Endothelium. J. Funct. Biomater. 2013, 4, 38-58. [CrossRef] [PubMed]

77. Teo, B.K.K.; Goh, K.J.; Ng, Z.J.; Koo, S.; Yim, E.K.F. Functional Reconstruction of Corneal Endothelium Using Nanotopography for Tissue-Engineering Applications. Acta Biomater. 2012, 8, 2941-2952. [CrossRef]

78. Koo, S.; Muhammad, R.; Peh, G.S.; Mehta, J.S.; Yim, E.K. Micro- and Nanotopography with Extracellular Matrix Coating Modulate Human Corneal Endothelial Cell Behavior. Acta Biomater. 2014, 10, 1975-1984. [CrossRef]

79. Muhammad, R.; Peh, G.S.L.; Adnan, K.; Law, J.B.K.; Mehta, J.S.; Yim, E.K.F. Micro- and Nano-Topography to Enhance Proliferation and Sustain Functional Markers of Donor-Derived Primary Human Corneal Endothelial Cells. Acta Biomater. 2015, 19, 138-148. [CrossRef]

80. Rizwan, M.; Peh, G.S.; Adnan, K.; Naso, S.L.; Mendez, A.R.; Mehta, J.S.; Yim, E.K.F. In Vitro Topographical Model of Fuchs Dystrophy for Evaluation of Corneal Endothelial Cell Monolayer Formation. Adv. Healthc. Mater. 2016, 5, 2896-2910. [CrossRef] 
81. Rizwan, M.; Peh, G.S.L.; Ang, H.P.; Lwin, N.C.; Adnan, K.; Mehta, J.S.; Tan, W.S.; Yim, E.K.F. Sequentially-Crosslinked Bioactive Hydrogels as Nano-Patterned Substrates with Customizable Stiffness and Degradation for Corneal Tissue Engineering Applications. Biomaterials 2017, 120, 139-154. [CrossRef]

82. Kim, E.Y.; Tripathy, N.; Park, J.Y.; Lee, S.E.; Joo, C.K.; Khang, G. Silk Fibroin Film as an Efficient Carrier for Corneal Endothelial Cells Regeneration. Macromol. Res. 2015, 23, 189-195. [CrossRef]

83. Nandakumar, A.; Truckenmüller, R.; Ahmed, M.; Damanik, F.; Santos, D.R.; Auffermann, N.; De Boer, J.; Habibovic, P.; Van Blitterswijk, C.; Moroni, L. A Fast Process for Imprinting Micro and Nano Patterns on Electrospun Fiber Meshes at Physiological Temperatures. Small 2013, 9, 3405-3409. [CrossRef] [PubMed]

84. Kim, M.Y.; Li, D.J.; Pham, L.K.; Wong, B.G.; Hui, E.E. Microfabrication of High-Resolution Porous Membranes for Cell Culture. J. Memb. Sci. 2014, 452, 460-469. [CrossRef] [PubMed]

85. Apel, P. Track Etching Technique in Membrane Technology. Radiat. Meas. 2001, 34, 559-566. [CrossRef]

86. Liang, J.; Li, B.; Wu, L. Recent Advances on Porous Interfaces for Biomedical Applications. Soft Matter 2020, 16, 7231-7245. [CrossRef] [PubMed]

87. Yabu, H. Fabrication of Honeycomb Films by the Breath Figure Technique and Their Applications. Sci. Technol. Adv. Mater. 2018, 19, 802-822. [CrossRef]

88. Liu, M.; Liu, S.; Xu, Z.; Wei, Y.; Yang, H. Formation of Microporous Polymeric Membranes via Thermally Induced Phase Separation: A Review. Front. Chem. Sci. Eng. 2016, 10, 57-75. [CrossRef]

89. Honig, F.; Vermeulen, S.; Zadpoor, A.A.; de Boer, J.; Fratila-Apachitei, L.E. Natural Architectures for Tissue Engineering and Regenerative Medicine. J. Funct. Biomater. 2020, 11, 47. [CrossRef]

90. Meek, K.M.; Knupp, C. Corneal Structure and Transparency. Prog. Retin. Eye Res. 2015, 49, 1-16. [CrossRef]

91. Scribante, A.; Poggio, C.; Gallo, S.; Riva, P.; Cuocci, A.; Carbone, M.; Arciola, C.R.; Colombo, M. In Vitro Re-Hardening of Bleached Enamel Using Mineralizing Pastes: Toward Preventing Bacterial Colonization. Materials 2020, 13, 818. [CrossRef] 